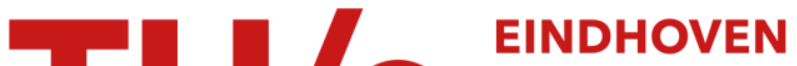 \\ UNIVERSITY OF \\ TECHNOLOGY
}

\section{Two centuries of central water management in The Netherlands}

Citation for published version (APA):

Lintsen, H. W. (2002). Two centuries of central water management in The Netherlands. Technology and Culture, 43(3), 549-568. https://doi.org/10.1353/tech.2002.0126

DOI:

10.1353/tech.2002.0126

Document status and date:

Published: 01/01/2002

Document Version:

Publisher's PDF, also known as Version of Record (includes final page, issue and volume numbers)

Please check the document version of this publication:

- A submitted manuscript is the version of the article upon submission and before peer-review. There can be important differences between the submitted version and the official published version of record. People interested in the research are advised to contact the author for the final version of the publication, or visit the $\mathrm{DOI}$ to the publisher's website.

- The final author version and the galley proof are versions of the publication after peer review.

- The final published version features the final layout of the paper including the volume, issue and page numbers.

Link to publication

\section{General rights}

Copyright and moral rights for the publications made accessible in the public portal are retained by the authors and/or other copyright owners and it is a condition of accessing publications that users recognise and abide by the legal requirements associated with these rights.

- Users may download and print one copy of any publication from the public portal for the purpose of private study or research.

- You may not further distribute the material or use it for any profit-making activity or commercial gain

- You may freely distribute the URL identifying the publication in the public portal.

If the publication is distributed under the terms of Article $25 \mathrm{fa}$ of the Dutch Copyright Act, indicated by the "Taverne" license above, please follow below link for the End User Agreement:

www.tue.nl/taverne

Take down policy

If you believe that this document breaches copyright please contact us at:

openaccess@tue.nl

providing details and we will investigate your claim. 


\section{Two Centuries of Central Water Management in the Netherlands}

\section{HARRY LINTSEN}

For two centuries the Rijkswaterstaat has been responsible for public works in the Netherlands. Founded in 1798, this national government agency, which now numbers twelve thousand employees, has left its mark on the country. The river landscape has been completely re-created. Deep-sea inlets and large inland saltwater lakes such as the Zuider Zee have been cut off from the sea, reducing the country's coastline by about 2,800 kilometers (from 3,400 to 650). More than 350,000 hectares of land have been reclaimed. The Rijkswaterstaat has also been involved in infrastructure development. At present there are in the Netherlands 3,000 kilometers of railway lines, around 4,000 kilometers of navigable waterways, 18,000 kilometers of cycle paths, and more than 100,000 kilometers of asphalt roads. Numerous "structural works," as they are known in civil engineering parlance, dominate the Dutch landscape: weirs, locks, storm surge barriers, bridges, viaducts, cloverleafs, tunnels, overpasses, and the like. Such structures have taken the place of other features-church spires, windmills, pollard willows, poplars - that once dotted the horizon.

The Rijkswaterstaat cannot claim full credit or responsibility for all these structures. Many other actors influence public works and infrastructure. Water boards, for instance, are responsible for local water control and for maintaining water quality. The Rijkswaterstaat operates in a complex environment. It has to deal with the various administrative bodies (the state, provinces, municipalities, and water boards) responsible for similar types of public works and infrastructure. It inhabits an ambiguous area between government and private enterprise, since many tasks can be carried out by private companies. Furthermore, the agency sees itself as a civil service organization confronted by numerous political parties and social

Dr. Lintsen is professor of the history of technology at the Technische Universiteit Eindhoven and the Technische Universiteit Delft. He is chair of the editorial team for the seven-volume Techniek in Nederland in de twintigste eeuw (Zutphen: Walberg Pers, 1998- ).

(C)2002 by the Society for the History of Technology. All rights reserved.

0040-165X/02/4303-0005\$8.00 
groups. Because public works and infrastructure are intertwined with so many different related sectors-agriculture, navigation, defense, environmental planning, and recreation, to name a few-these interest groups remain diverse. In its capacity as a professional organization the Rijkswaterstaat must also closely monitor relevant scientific and technological developments.

JULY

2002

VOL. 43

The Rijkswaterstaat's central role in Dutch society is taken for granted. The battle against water is vital to the country's survival, and it is a battle that the Rijkswaterstaat has fought successfully. But in its two hundred years the agency has also known less prosperous times. It has even experienced periods of acute crisis, in which social support for its operations faded and its existence hung by a thread. The changing tides of the Rijkswaterstaat are the theme of this essay. The questions posed are these: What has been the Rijkswaterstaat's role over the past two centuries in the shaping of the Netherlands, and what are the social and technological developments that have particularly influenced the way in which the Rijkswaterstaat operates? ${ }^{1}$

In answering these questions we may distinguish three distinct periods. During the first, which I will call the autocratic-traditional period, lasting from 1798 to 1850 , the creation of the Rijkswaterstaat introduced a new element into the history of Dutch water management. The agency had to prove itself against powerful water boards with a rich tradition. It desperately sought acknowledgement by the national and provincial administrative elites. Only under the autocratic rule of King Willem I (1813-40) did the Rijkswaterstaat achieve a measure of prestige, thanks in part to its success with a few large water management projects. This period also saw the founding of a professional school for Rijkswaterstaat engineers.

From 1850 to 1930 , an era that I will call the democratic-mechanized period, a democratic polity arose in which the upper class had a central role. This drastically changed administrative relations, to the great benefit of the Rijkswaterstaat, which obtained a solid position within the Dutch water management system. Engineers succeeded in resolving the main problems of water management, and other important structural works were realized under their control or with their assistance. The introduction of steam and other new technologies was essential to this success. At the

1. Beginning in 1993 I headed an extensive research project on the history of the Rijkswaterstaat, administered by the Foundation for the History of Technology, in Eindhoven. That project culminated in the publication of A. Bosch and W. van der Ham, Twee Eeuwen Rijkswaterstaat, 1798-1998 (Zaltbommel, 1998). In addition to that book and various articles, the project produced three Ph.D. theses: W. van der Ham, Heersen en Beheersen: Rijkswaterstaat in de twintigste eeuw (Zaltbommel 1999); Toon Bosch, Om de macht over het water: De nationale waterstaatsdienst tussen staat en samenleving, 1798-1849 (Zaltbommel 2000); and Eric Berkers, Technocraten en Bureaucraten: Ontwikkeling van organisatie en personeel van de Rijkswaterstaat, 1848-1930 (Zaltbommel, 2002). 
beginning of the twentieth century the Rijkswaterstaat went through a difficult period, coming in for heavy criticism from both politicians and press for its inadequate response to new challenges (for example, the introduction of reinforced concrete and the automobile) and new technological and scientific developments (among others, the application of scale models).

The years 1930-95 constitute a third era in the history of the Rijkswaterstaat, which I call the technocratic-scientific period. In 1930 the Rijkswaterstaat was radically reorganized, the main goal being the creation of new, specialized departments that would allow the agency to experiment with new methods and advanced designs. Soon it had regained the confidence of the political establishment, and reached new heights of power and prestige after World War II. But in the 1970s its fortunes suddenly changed again. The agency was accused of destroying the landscape and harming the environment. Critics called it "a state within a state," a technocratic organization that dominated and manipulated water management and infrastructure in the Netherlands.

The end of the twentieth century would seem to mark another turning point in the history of the Rijkswaterstaat and public works in the Netherlands, a hypothesis I will propose at the end of this essay.

\section{The Birth of the Rijkswaterstaat}

Historically, water threatened the Netherlands in three ways. ${ }^{2}$ A sinking landmass and rising sea levels created problems for draining away excess surface water. Over the centuries, drastic measures such as the building of polders and the use of mechanical drainage were required to ensure that the coastal regions of the country remained habitable. ${ }^{3}$ Second, over the course of time the sea was given ever more freedom. In the ninth century the Dutch seacoast was more or less uninterrupted except by river estuaries and inlets. In subsequent centuries storms reshaped the coast in various places, creating deep inlets in the southwest and a new inland sea in the heart of the delta, the Zuider Zee. The coastline grew from around 800 kilometers

2. Gerard P. van de Ven, ed., Man-Made Lowlands: History of Water Management and Land Reclamation in the Netherlands (Utrecht, 1993), is an excellent overview of the history of Dutch public works, notably in the period from 800 to 1800. Unfortunately, the book does not list sources or contain a bibliography. See also T. Stol, Wassend water, dalend land: Geschiedenis van Nederland en het water (Utrecht, 1993). A more popular but definitely informative source is Johan van Veen, Dredge, Drain, Reclaim: The Art of a Nation, 5th ed. (The Hague, 1962).

3. For the different pumping techniques, see H. A. Visser, Zwaaiende wieken: Over de geschiedenis en het bedrijf van de windmolens in Nederland (Arnhem, 1979); K. van der Pols, De ontwikkeling van het wateropvoerwerktuig in Nederland 1770-1870 (Delft, 1984); and Harry W. Lintsen, "Stoom en bemaling," in Geschiedenis van de Techniek in Nederland: De wording van een moderne samenleving 1800-1890, ed. Harry W. Lintsen et al. (Zutphen, 1993), 4:131-49. 
to about 3,400 kilometers at the beginning of the twentieth century, becoming ever more fragile. Third, when one thinks of the threat of the waterwolf one thinks in the first place of the sea, but rivers have constituted just as great a threat to Dutch welfare. By the fourteenth century most Dutch rivers were lined with dikes, yet the land was frequently plagued by

JULY

2002

VOL. 43 river flooding. Poor-quality riverbeds full of sandbars and other obstacles hindered not only water flows but also the movement of ice downriver. In hard winters ice dams would form, forcing up water levels and causing water to overflow or break through the dikes. The river systems also developed bottlenecks. At times of high water levels, water and ice would force their way to the sea through a small number of river estuaries that were in a poor state of repair. There was also the problem of poor water distribution between the different branches of the Rhine-the Waal, the Neder Rijn, and the IJssel. So much water passed through the Waal that the Neder Rijn and the IJssel were in danger of silting up.

Dutch success in the battle against water was, in the first place, the result of good organization at a local level. Every community had to take care of its own drainage systems without overburdening others'. The resultant public works system, based on the careful management of local administrators and a high degree of involvement on the part of local inhabitants whose knowledge of the local situation was excellent, was incredibly complicated. The system at least guaranteed that the low-lying areas of the Netherlands remained habitable. Moreover, knowledge and experience were successfully deployed in winning back land by building dikes and polders. Between 1600 and 1800 more than a hundred lakes and pools, with a total area of about 60,000 hectares, were empoldered. Still, this reclamation effort was slight compared to the 900,000 hectares of land that had been lost since the year $800 .{ }^{4}$

By the end of the eighteenth century more than a thousand different organizations were somehow or other involved in Dutch public works. At the risk of exaggerating slightly, one might assert that each of these had its own unique history and administrative structure. They had developed in different centuries and were held in varied degrees of esteem. Some controlled large areas and were completely occupied with taking care of their extensive responsibilities for water control. Others had only one or two canals to maintain alongside a diversity of other tasks. The larger water boards had their own technical staff, while the smaller organizations either turned to the local authority for expertise or temporarily contracted personnel who possessed the required expert knowledge. It was a rich diversity of groups, reasonably well-equipped to deal with local drainage problems, but major disadvantages arose when public works problems extended beyond the borders of local areas. This was notably the case with river

4. E. Schultz, Waterbeheersing van de Nederlandse droogmakerijen (Lelystad, 1992). 
problems and the maintenance of sea dikes and dunes. Cooperation within the fragmented public works system was sometimes difficult.

In this context the provinces and the larger water boards in the province of Holland played an important role, but even for them a number of crucial problems proved difficult to resolve. If the river network as a whole was to be improved it would require cooperation among the provinces of Holland, Utrecht, Overijssel, and Gelderland, and also with the numerous public works organizations situated in those areas. ${ }^{5} \mathrm{~A}$ measure of success in this regard was achieved after 1770 in the case of the works required to stabilize the division of water flows among the various branches of the Rhine, but it was preceded by years of debate and argument, and in the end only under pressure from Prussia were all the disagreements settled. The provinces were unable to agree on further structural improvements despite a number of disastrous river floods in the eighteenth century. The problem seemed unresolvable under the existing circumstances, and ultimately it contributed to the establishment of the Rijkswaterstaat.

It should be noted, however, that the Rijkswaterstaat was not set up in reaction to any crisis in the public works sector. Rather, it was more a result of political changes in the Netherlands in 1795, the year that marked the end of the Republic of the Seven United Netherlands, when French troops, supported by fleeing patriots, invaded. Many welcomed the revolution, which led to the creation of the Batavian Republic. Since the 1770s patriots in the Netherlands had formed a political movement inspired by Enlightenment ideals and radical democratic views and animated by the revolutionary political changes taking place in America and Western Europe. ${ }^{6}$ They planned to replace the Republic of the Seven United Netherlands with a "united fatherland" that would feature a parliament elected by the people and a centrally governed state. In such a political structure, a centralized public works body seemed desirable. The Batavian Republic provided the opportunity for revolutionary change, but the process would not be easy.

\section{The Autocratic-Traditional Period (1798-1850)}

The years 1795 to 1813 were particularly turbulent in the Netherlands, characterized by vehement political discussions and rapid power changes that were heavily influenced by events in France. ${ }^{7}$ On the one hand, there was the formation of a united state; on the other hand, the provinces

5. Gerard P. van de Ven, Aan de wieg van de Rijkswaterstaat: Wordingsgeschiedenis van het Pannerdens Kanaal (Zutphen, 1976).

6. See, for instance, Simon Schama, Patriots and Liberators: Revolution in the Netherlands, 1780-1813 (New York, 1992).

7. On the autocratic-traditional period, see Toon Bosch, Om de macht over het water (n. 1 above), and Bosch and van der Ham, Twee eeuwen Rijkswaterstaat (n. 1 above), esp. part 1. 
JULY

2002

VOL. 43

achieved great autonomy. The coup d'état of 1798 strengthened the centralized power and made the provinces more subordinate. Under the slogan "unity, simplicity, and indivisibility" an agency was set up in that year "for the administration of all that which pertains to public works." The Rijkswaterstaat was born. In 1801 political reform restored the power of the provinces and undermined the position of the newly created Rijkswaterstaat. When Napoléon Bonaparte crowned himself Emperor of France in 1804 things changed again. During his war against England, Napoléon sought the support of the Batavian Republic and endeavored to introduce a powerful monarchical regime in the republic. In 1806 he went a step further, turning the republic into the Kingdom of Holland and placing his brother Louis-Napoléon on the throne. In 1810 Napoléon annexed the Netherlands to France, a situation that would last until 1813. The Rijkswaterstaat was incorporated into France's national Service des Ponts et des Chaussées, a powerful military and bureaucratic organization. ${ }^{8}$ Opposing these French influences was the English tradition, with its accent on private entrepreneurship and informal, equality-driven relations between traditionally educated technicians. But the English influence in the Netherlands was minor in the first half of the nineteenth century, certainly in comparison with a country such as the United States. ${ }^{9}$

After the fall of Napoléon in 1813 political reforms diminished. The Netherlands became a kingdom under the House of Oranje-Nassau, and Willem I was made its sovereign. After 1815 the Kingdom of the Netherlands also incorporated the southern Netherlands, now Belgium, but that union was short-lived. Belgium rebelled in 1830 and, after a protracted military and political struggle, gained its independence in 1839. The Kingdom of the Netherlands became a centralized state under an authoritarian monarch, in which the power of the provinces was lost and parliament had little influence.

The relationship between the state, the provinces, and the water boards was a subtle one. The monarch had ultimate responsibility for everything concerning public works, but in practice that responsibility was chiefly delegated to the provinces. They controlled the water boards, the provincial public works, and even the main river dikes and sea defenses. They were also responsible for state-level public works such as canals, sluice complexes, and coastal sea defenses that served national interests. The Rijkswaterstaat had an important part to play in executing these tasks, which put the agency in an ambiguous position. It was a state agency in which some of the engineers were paid by the national government but carried out jobs at both provincial and national levels. Other engineers were paid by the

8. Harry W. Lintsen, Ingenieurs in Nederland in de negentiende eeuw: Een streven naar erkenning en macht (The Hague, 1980), 59-65.

9. Todd Shallat, Structures in the Stream: Water, Science and the Rise of the U. S. Army Corps of Engineers (Austin, Tex., 1994), 40-42, 205-7. 
provinces but were also expected to do work for the central government. In effect, the agency had two employers: the nation and the provinces. The provinces had gained their influence not so much from forces that wished to restore old relationships as from the desperate financial situation of the state, which dated from the Batavian and French period. Meanwhile, local and regional public works remained the domain of the water boards. Not even Louis-Napoléon and Napoléon Bonaparte had succeeded in reducing their autonomy. It was only in cases where the state subsidized waterrelated works of national importance that it could exercise any influence.

Even in the absence of a centralized system, Willem I managed to leave his mark on public works and infrastructure during his reign (1813-40). Dubbed the "merchant king" because he promoted trade and industry and "king of the canals" because he was responsible for the digging of nearly 500 kilometers of new canals and for improving many other shipping routes, he ruled with indefatigable energy as an enlightened despot. ${ }^{10} \mathrm{He}$ might equally have been hailed "king of the roads", as it was under his rule that a road network first emerged, or "king of the new land," because he initiated various reclamation projects, including the empoldering of the Haarlemmermeer, the biggest reclamation job of the nineteenth century. ${ }^{11}$ The Rijkswaterstaat profited from his energy and his autocratic style, enjoying huge investments, big projects, and plenty of work, especially in the 1820s.

But the agency's prestigious position was not easily achieved. The Rijkswaterstaat had to prove itself in an environment in which the most important posts were filled by members of the aristocracy and the upper classes. The first engineers were predominantly the sons of tradesmensurveyors, carpenters, windmill builders, and the like. With the exception of a handful of people in top positions, the politicians, administrators, and civil servants working at the ministries and in the provincial governments certainly did not see the Rijkswaterstaat engineers as their social equals. ${ }^{12}$

The first generation of engineers were trained on the job, but for the next that was not enough. Partly because of the French influence in the country, these second-generation engineers were educated at military academies. The first public works training in the Netherlands dates from 1805, at the General Theoretical and Practical School for Artillery, Military Engineering and Public Works in Amersfoort. Eventually the center of engineering education shifted to the Royal Military Academy in Breda.

10. See R. Filarski, Kanalen van de Koning-Koopman: Goederenvervoer, binnenscheepvaart en kanalenbouw in Nederland en België in de eerste helft van de negentiende eeuw (Amsterdam, 1995).

11. Harry W. Lintsen, R. A. Lombaerts, and R. Moerenhout, "De droogmaking van de Haarlemmermeer: Wind of stoom," in Nederlandse ingenieurs en hun kunstwerken: Tweehonderd jaar civiele techniek (Wonderen der techniek), ed. M. L. ten Horn van Nispen, H. W. Lintsen, and A. J. Veenendaal Jr. (Zutphen, 1994), 31-40.

12. On the development of a cadre of general public works engineers, see Lintsen, Ingenieurs in Nederland. 
Completion of training there became an admission requirement for the Korps Ingenieurs van de Algemene Waterstaat, or engineering corps for general public works, which meant that the social background of the engineers changed as they came to be chiefly recruited from the upper classes. The requirement also served to reinforce the Rijkswaterstaat's military character.

Despite their theory-oriented schooling, the work of these engineers

JULY

2002

VOL. 43 remained very practical. ${ }^{13}$ It was not possible to really grasp the problems confronting the Rijkswaterstaat from a purely theoretical angle. Rather, they had to manage with the time-tested knowledge passed down from generation to generation. The impressive achievements of the first half of the nineteenth century were made possible because the Rijkswaterstaat added two important ingredients to the trade-oriented, practical aspect of hydraulic engineering: knowledge consolidation and organizational capacity. The Rijkswaterstaat collected local and regional know-how from all corners of the country, an undertaking that involved all parts of the organization. The strength of this centrally organized reserve of knowledge was revealed in practice in all facets of hydraulic engineering, from the preparing and carrying out of large projects to long-term maintenance and management. Large projects also drew heavily on the organizational capacity of the agency and the state to establish credibility, to bring knowledge to bear, to raise huge sums from taxation, to conduct complex logistic operations, and to sometimes mobilize hundreds of laborers.

Despite competence in all these areas, the Rijkswaterstaat was unable to resolve one of the most important problems it had been created to address. Flooding caused by rivers still regularly threatened the delta. One of the main reasons was the lack of consensus among hydraulic engineers and administrators about how to approach the problem. ${ }^{14}$ In many places the riverbed was nothing more than a series of channels running through shallows, sandbars, and islands. ${ }^{15}$ This hindered the movement of ice and of large volumes of water. There were two conflicting solutions to this problem: create overflows or deepen the channels. The first involved lowering the dikes at strategically selected spots. Water would spill over these low sections and flow downstream over uninhabited land until it joined up with the same or a different river. In periods of high water overflows would provide temporary side-branching discharge possibilities. Deepening channels of course involved the reconstruction of the riverbed. A central chan-

13. See Geert Verbong, “Techniek, beroep en praktijk," in Lintsen et al., Geschiedenis van de techniek in Nederland (n. 3 above), 5:291-303.

14. See Toon Bosch and Gerard P. van de Ven, "Rivierverbetering," in Lintsen et al., Geschiedenis van de techniek in Nederland, 2:103-27.

15. The problem was not that the riverbed rose significantly through sedimentation. Dutch rivers are sediment-poor, and the speed of the water was generally sufficient to carry off such sediment as did exist. Dike elevation because of sedimentation had only rarely been necessary in past centuries. 
nel, built to standard dimensions, would take the place of the natural series of channels. Water and ice could thus be speedily conveyed to the sea. Ultimately the whole discussion stagnated, and no choices were made.

But there was also progress. During the Batavian era the so-called river correspondence was introduced. This revolved around a centrally organized warning system in which engineers stationed at various posts passed information about water levels, ice dams, the threat of dikes bursting, and possible dike breaches to each other and to the state authority. Also new was the compilation of a general river ordinance, unique in its breadth and detail. In 1829 the state began to map rivers, a project that took almost forty years but one that proved invaluable in throwing light on the problem of the rivers. Work on mapping was accompanied by the introduction of new, uniform river-level gauges.

Other events besides the regularly recurring floods put the Rijkswaterstaat's credibility to the test. In 1830 Belgium broke away, and Willem I embarked on an expensive and lengthy period of mobilization. Investments in public works and infrastructure fell dramatically in the 1830s. Later, though, a number of important decisions would be taken, particularly in relation to the construction of the Rhine railway (1838) and the reclaiming of the Haarlemmermeer (1839). The reign of Willem I ended on a low note in 1840 with his abdication. The Rijkswaterstaat was rapidly downgraded. It became a marginal organization of minimal means with unimportant tasks to fulfill and a regular victim of reorganizations and spending cuts. Its management was also considerably weakened. Prominent engineers died or retired, and their successors did not have the same authority within or outside the agency. Those engineers drawn from higher social circles and educated at the military academy were still too young to be promoted to higher positions.

\section{The Democratic-Mechanized Period (1850-1930)}

The malaise within the Rijkswaterstaat would last until 1848, when liberal reformers led by Jan Rudolf Thorbecke staged a peaceful revolution. ${ }^{16}$ This was also the point at which the influence of the monarchy ended, and parliament seized the opportunity to affect policy. Administrative relations, particularly between the national government, the provinces, and the municipalities, were more clearly outlined in legislation. In time this led to a clear division of national and provincial water management responsibilities and the establishment of provincial public works departments. The Rijkswaterstaat could now devote itself completely to overseeing public works and executing projects of national importance.

16. See Bosch and van der Ham, Twee eeuwen Rijkswaterstaat (n. 1 above), and van der Ham, Heersen en Beheersen (n. 1 above), esp. part 1. 
The liberal élan was infectious. Public works engineers spoke of "a newborn country" and believed that the time was ripe for major undertakings to construct railways, improve rivers, excavate new canals, and close off the Zuider Zee. They had to exercise a little patience, as state finances first had to be put in order, but soon expenditures on public works and infrastructure rose sharply, from around three million guilders in 1850 to over sixteen million guilders in 1870 .

The deadlock that had halted the debate on river improvements was finally broken in $1850 .{ }^{17}$ In that year the Rijkswaterstaat compiled a lucid twenty-five-page report in which it opted against creating overflows and in favor of redirecting and deepening river channels. The Rijkswaterstaat also proposed to dig a new and much larger estuary for the Waal (the main branch of the Rijn), to be known as the Nieuwe Merwede. Later it was decided that the other important river of the Netherlands, the Maas, should also be given a new estuary, the Bergse Maas. ${ }^{18}$ This decision precipitated an enormous project that would occupy generations of engineers, contractors, and laborers. Hundreds of kilometers of river were systematically reshaped, and the landscape was changed completely. Each river was given a riverbed of standard width and depth. Sandbars and islands were leveled, dredged, or connected to the riverbank via levees. At the same time old groins, structures, and boscages in the river forelands were cleared away, as these, too, hindered the flow of ice and water in the winter and spring. New groins and levees were built to control the rivers. In the process, central channels of predetermined widths were built in the rivers, a strategy devised by Italian hydraulic engineers in the seventeenth century and tested and proven at the beginning of the nineteenth century in Germany. Empirical methods were used to determine the desired width. Theoretical models of water flows that could show how they contributed to channel deepening were lacking, so the dimensions of existing river sections with favorable and stable flow profiles were taken as starting points. Where possible, engineers also took advantage of tidal forces. The river had to be of such a shape that on its way to the sea it broadened gradually. Details relating to the volume of water to be transported and the depth of the navigation channel were also taken into account. Whether or not the standard widths had to be adapted would become apparent only with experience.

17. See also Bosch and van de Ven, "Rivierverbetering"; G. van Diesen, "Beteekenis der rivierverbetering," in Gedenkboek Koninklijk Instituut van Ingenieurs, 1848-1898 (The Hague, 1998); H. van Heiningen, Diepers en delvers (Zutphen, 1992); and H. P. N. Nusteling, De Rijnvaart in het tijdperk van stoom en steenkool, 1831-1914 (Amsterdam, 1974).

18. A number of other proposals were also put forward, such as improving river dikes, reinforcing the Linge Works and the Dief dike line, and closing off the many channels in the Biesbos. See "Rapport van J. H. Ferrand en L. J. A. van der Kun nopens hetgeen tot verbetering der Nederlandsche rivieren zoude kunnen bewerkstelligd worden," in Verslag aan den Koning over de Openbare Werken (The Hague, 1854). 
The river improvement project was a great success. The last big flood of the nineteenth century occurred in $1876 .{ }^{19}$ The Rijkswaterstaat had thus paid off an old debt. Established in 1798 to avert dangerous river flooding, the Rijkswaterstaat had finally, almost a hundred years later, achieved that end.

The Rijkswaterstaat also became involved in other prestigious projects. It left its mark on railway policy, for instance. ${ }^{20}$ Until 1860 rail development had been left to private initiative, and the results had been meager. Only 335 kilometers of railway track had been built, operated by four different companies. In 1860 parliament decided that the state should create a proper railway network, and a special department was established for that purpose. At first a disproportionate number of engineers seconded from the Rijkswaterstaat to the new department took charge of railway construction, while a private company had responsibility for management. By 1870 there were 1,000 kilometers of rail track, and by the end of the century the rail network had grown to more than 2,000 kilometers.

Another big project was the excavation of the North Sea canal, begun in 1865. ${ }^{21} \mathrm{~A}$ more direct connection with the sea that passed straight through the dunes, the canal provided easy access to Amsterdam for increasingly large seagoing vessels. Again, the actual excavation work was left in the hands of a private company. The Rijkswaterstaat assessed the plans and supervised the job. Various Rijkswaterstaat engineers were employed by the contractor for the duration of the project and put in charge of the works. Around the same time Rotterdam also acquired a new connection with the sea, the Nieuwe Waterweg. ${ }^{22}$ This massive project was entirely taken on by the Rijkswaterstaat, from design to execution and management, because the Nieuwe Waterweg was viewed as an aspect of the river improvement project and so seen as a central government project.

Even though these projects did not always proceed smoothly, they helped to boost the prestige of the Rijkswaterstaat. There were even some

19. The Dutch climate has changed since the end of the Little Ice Age in the nineteenth century, with fewer severe winters and less ice formation. The degree to which river improvements are responsible for better water control and less flooding therefore cannot be definitively established.

20. See also J. H. Jonckers Nieboer, Geschiedenis van de Nederlandse spoorwegen, 1832-1938 (Rotterdam, 1938), and A. J. Veenendaal, "Spoorwegen," in Lintsen et al., Geschiedenis van de techniek in Nederland, 2:129-64.

21. See M. L. ten Horn van Nispen, "De doorgraving van Holland op zijn smalst," in van Nispen, Lintsen, and Veenendaal, Nederlandse ingenieurs en hun kunstwerken (n. 11 above), 49-58; H. Wortman and G. J. van den Broek, Geschiedenis en beschrijving van het Noordzeekanaal (Amsterdam, 1909).

22. A. T. de Groot and A. B. Marinkelle, De waterweg langs Rotterdam naar zee, 18661916 (The Hague, 1916); M. L. ten Horn van Nispen, "De nieuwe waterweg van Rotterdam naar zee," in van Nispen, Lintsen, and Veenendaal, Nederlandse ingenieurs en hun kunstwerken, 59-69; J. A. Ringers, Caland en de betekenis van zijn werk voor Rotterdam (Rotterdam, 1953); and C. Wiskerke, De scheepvaartwegen van Rotterdam naar zee (Rotterdam, 1948). 
who feared that an engineers' pressure group, independent of parliament, might develop.

The success of the Rijkswaterstaat did not rest solely on its expertise and organizational capabilities. The adoption of a new basic technology, steam, was crucial. Steam dredges were used in river improvement projects, steam pumping engines in difficult drainage situations, steam pile drivers

JULY

2002

VOL. 43 for large foundations, steam shovels for digging canals, and so on. The large-scale deployment of steam power rendered the various water-control projects feasible. For example, when it came to constructing the Nieuwe Merwede, a new section of river had to be excavated through a swampy and uninhabited area. ${ }^{23}$ To accomplish this, a number of channels were widened and connected with each other. The engineers maintained that the best way of reaching the desired depth would be by means of natural erosion, but the riverbed was too hard for that method to be practical. In 1861 the Rijkswaterstaat decided to bring in steam dredges. By 1874 the new river had the desired depth of 3 meters below low-water level almost everywhere. Even so, it was necessary to regularly dredge the river. A similar situation arose later with the construction of the Nieuwe Waterweg. There the engineer in charge of works for many years stubbornly held on to the idea that tidal flows would automatically give the new river section the proper breadth and depth. After his departure, whole batteries of dredges were brought in. By 1896 the waterway was the right depth, about thirty years later than planned and at five to six times the original budget.

In reality, steam dredging compensated for a lack of knowledge of hydrodynamics and of the ways in which rivers flow and the sea moves. Changes in the engineering profession had not yet led to a consolidated and useful theoretical body of knowledge on hydraulic engineering. The establishment of the Royal Academy of Civil Engineers in 1842 (which preceded the University of Technology in Delft) represented the transition from a military to a quasi-academic educational system for engineers. When the Royal Institute of Engineers, the first engineering society in the Netherlands, was established in 1847 it created a new information center for hydraulic engineering. The institute channeled debates about topical technical issues, organized excursions, published information on public works activities, translated articles written in other languages, and provided extensive book reviews. In this way, Dutch civil engineers not only gained access to more adequate theoretical knowledge but also to a broad and internationally oriented professional community. Developments in steam technology were also closely followed within the institute's community.

23. Bosch and van de Ven, "Rivierverbetering" (n. 14 above); van Heiningen; C. Lely, "Rivieren en rivierwerken," in Waterbouwkunde, ed. N. M. Henket, C. M. Schols, and J. M. Telders (The Hague, 1890); C. B. Schuurman, "De Merwede," in Gedenkboek Koninklijk Instituut van Ingenieurs, 1848-1898 (n. 17 above). 
Around 1900 the pace of the Rijkswaterstaat's activities slowed as two major projects begun in the latter half of the nineteenth century reached completion. Consequently, investments in public works and infrastructure fell sharply in the first two decades of the twentieth century. But there was no shortage of plans during this period-for projects to improve river navigation, to deepen the North Sea canal and build a new sea sluice, to link Amsterdam to the Rhine, to create a road network for the increasing amount of motorized traffic, and to reclaim the Zuider Zee.

The outbreak of the First World War halted these plans. Although the Netherlands remained neutral, wartime crippled government finances, and decision-making processes stagnated inside and outside of the Rijkswaterstaat. By the 1920s, politicians and press had begun to criticize the Rijkswaterstaat for being too bureaucratic and too hierarchical. Worse was the criticism that the service had difficulty incorporating German and American technological advancements. Germany had introduced steel and electrical mechanization, reinforced concrete, and scale models. The Americans were demonstrating how building processes could be made more economical and efficient. When reinforced concrete was introduced to the hydraulic engineering sector at the beginning of the twentieth century, the Rijkswaterstaat was criticized for being too cautious with this new material. At the time of the canalization of the Maas in the 1920s, disagreements arose within the Rijkswaterstaat about the introduction of new types of sluices invented in Germany. ${ }^{24}$

This led the minister of public works to accuse the agency's managers of indecision, lack of expertise, and an overly conservative attitude. A hydrodynamic laboratory for scale-model research was finally established in 1933, after years of discussion between the Rijkswaterstaat engineers (was such research necessary?) and two ministries (which one should be responsible for the new institute?). ${ }^{25}$ In the end it was assigned neither to the Rijkswaterstaat nor to the Ministry of Public Works but to the Ministry of Education, Arts, and Science. Meantime the Rijkswaterstaat's most ambitious and prestigious project, to close off the Zuider Zee, went badly wrong. ${ }^{26}$ In 1918 the minister of public works declared that the Rijkswaterstaat's organization was too inefficient and assigned the project to a different agency. The project had been hampered by the resistance of a number of prominent engineers who questioned whether the proposed barrier dike was practically possible and economically viable. Some were relieved when

24. See also C. Disco, "Maaskanalisatie en Maasverbetering, 1900-1940," in Techniek in Nederland in de twintigste eeuw, ed. Johan Schot, Harry Lintsen, and A. Rip, vol. 1 (Zutphen, 1998), 89-110.

25. J. M. Dirkzwager, Water: Van natuurgebeuren tot dienstbaarheid (The Hague, 1977).

26. See J. T. Thijsse, Een halve eeuw Zuiderzeewerken (Groningen, 1972), and K. Jansma, Lely bedwinger der Zuiderzee (Amsterdam, 1954). 
the project did not materialize for the Rijkswaterstaat; it had, to their minds, been a far too risky proposition.

\section{The Technocratic-Scientific Period (1930-1995)}

JULY

2002

VOL. 43

In 1930, with the Netherlands on the verge of economic depression, things began to look up for the Rijkswaterstaat. ${ }^{27}$ The appointment of a new general director, civil engineer J. A. Ringers, turned out to be decisive. Ringers energetically tackled a number of major problems, gathering around himself a team of competent engineers and embarking on a reorganization of the agency. Crucial to the reorganization process was the setting up of specialized departments for specific projects and techniques. There was a department for bridges, one for sluices and weirs, one for the upper reaches of rivers and one for the lower reaches of rivers. These existed alongside-and were in some cases superior to-the regional departments that until then had formed the backbone of the Rijkswaterstaat. Reorganization brought improved functionality and an increased level of political trust.

During the depression years the Rijkswaterstaat was one of the few government organizations not hit by spending cuts. It succeeded in getting a kind of "Dutch New Deal" off the ground, an extensive infrastructure program that had already been put in place in the 1920s and continued into the 1930s. The Rijkswaterstaat invested heavily in roads, canals, river canalization, and reclamation, becoming in the process the country's largest public employer. At the same time it introduced many new techniques and fully enjoyed the benefits of scientific advancement. In certain vital hydraulic engineering areas, such as soil mechanics and hydrodynamics, theoretical approaches led to important results. New design methods, such as the use of scale models, became popular. A breakthrough was made in the "scientification" of techniques_as evidenced, for instance, in the new phase of river improvement.

Until 1900 river improvements had been linked especially to protection from flooding. Germany had always insisted that high priority should be given to navigability, but to no avail. Then suddenly river navigation became an objective equal in importance to flood protection, and remained so until the Second World War. A new river project began in 1909 on the Waal, the most important Dutch water thoroughfare. Up to the German border the river's navigation channel was made 3 meters deep and constructed in such a way that it would retain that depth. In 1915 it was decided that the Maas should also be made navigable to facilitate the trans-

27. See Bosch and van der Ham, Twee eeuwen Rijkswaterstaat (n. 1 above); van der Ham, Heersen en Beheersen (n. 1 above); and C. Disco, "Waterstaat," in Schot, Lintsen, and Rip, Techniek in Nederland in de twintigste eeuw, vol. 1. 
port of coal from mines in the southern Netherlands. This was the first time that the Rijkswaterstaat had involved itself in the building of large weir and sluice complexes. ${ }^{28}$ Its engineers looked abroad for inspiration. The project was extended in the 1920s and 1930s with the building of a new canal, the Julianakanaal, running parallel to a problematic section of the Maas. One of the three locks in this canal featured the greatest difference in water level in the country, about 12 meters. The floors and walls of the lock were constructed of reinforced concrete as a single structure, and the large lifting doors were designed in the hydrodynamic laboratory established in 1933. The project was rounded off in the 1930s with the removal of some bends in the river, the construction of a new dam, and further regulation. The large-scale flooding of 1926 gave rise to this final part of the project. ${ }^{29}$ Dependence on countries such as Germany for sluice and weir designs decreased, partly because of the contribution of specialized Rijkswaterstaat departments and the hydrodynamic laboratory.

In the 1930s, the hydrodynamic laboratory was also asked to develop a plan for the canalization of the Neder Rijn. The rationale behind this project reached much further than flood control and navigability; its purpose was to control Dutch water provision systems on a macro scale. In the Netherlands, water supplies for transportation, domestic consumption, and industry and agriculture depended (as they still do) on the big rivers, whose flows varied throughout the year. In coastal areas there was also the added complication of silt formation and a gradual increase in the salinity of groundwater and surface water. Pollution added a further complication, as worsening water quality began to affect freshwater supplies in cities.

Since the end of the nineteenth century the Rijkswaterstaat had been increasingly aware of the interconnections among these problems. In the 1930s that perception resulted in an approach that viewed the big rivers, part of the canal network, the IJsselmeer, and the closing off of sea inlets as part of a single large-scale system that could regulate Dutch domestic water supplies. The canalization of the Neder Rijn became a crucial part of this plan, with the dam and sluice complex at Driel playing an important part. This complex, sometimes known as the tap of the Netherlands, was completed in 1970 (fig. 1). It was designed to be left open when water levels were normal or high, but in periods of low water, which might occur during six to nine months of the year, the dam would remain closed so that water from the Rhine would flow into the Waal and the IJssel. Because of two other weirs the Neder Rijn remained navigable. The IJsselmeer thus received enough freshwater from the IJssel to supplement the northern Netherlands in times of drought. The Haringvliet locks were built in the

28. See G. J. Arends, Sluizen en stuwen: De ontwikkeling van de sluis- en stuwbouw in Nederland tot 1940 (Delft, 1994).

29. See C. W. Lely, "De verbetering van de Maas voor groote afvoeren," De Ingenieur 51, no. 24 (1931): 147-50. 
JULY

2002

VOL. 43

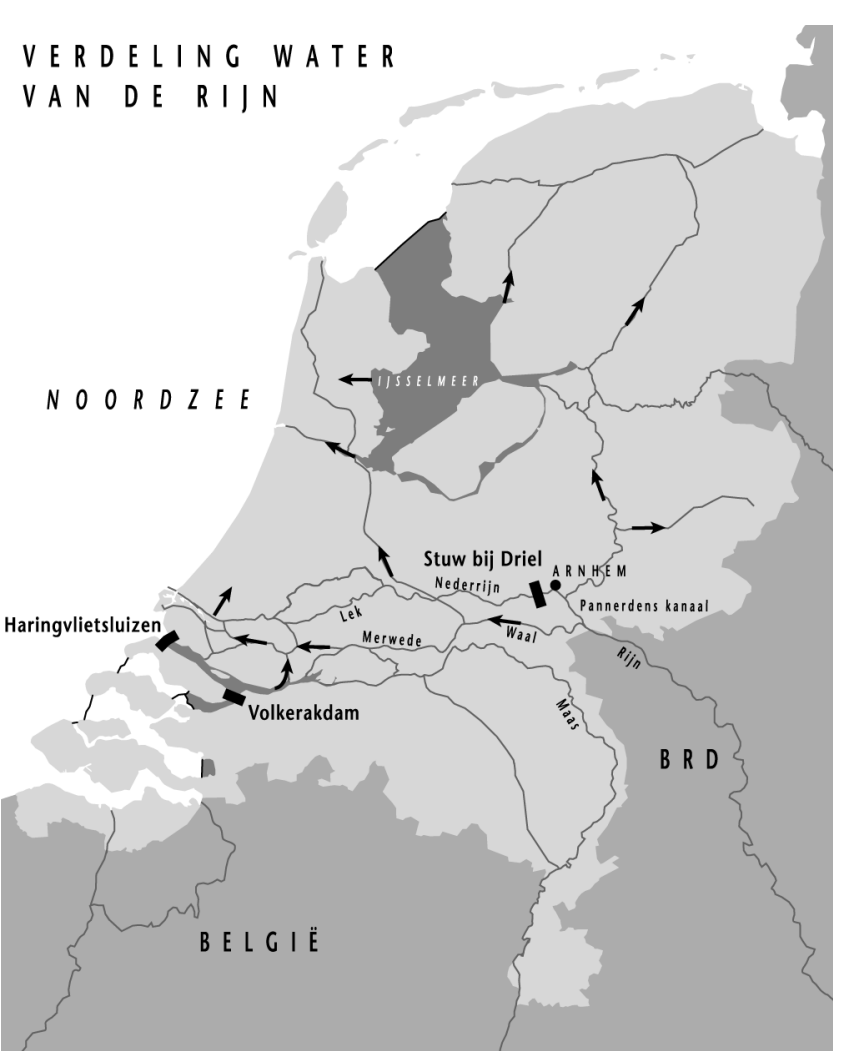

FIG. 1 With the introduction of the Haringvliet locks in 1971, the main system for distributing the flow of the Maas and the Rhine was complete. The dam in Driel (Stuw bij Driel) and the Haringvliet locks (Haringvlietsluizen) were key components of this system. The dam divided the water carried by the Pannerdens Kanaal between the IJssel (and the IJsselmeer) and the Nederrijn-Lek. The Haringvliet locks could force water from the Maas and the Rhine in the direction of the Nieuwe Waterweg in order to prevent the inflow of salt water. (Johan Schot, Harry Lintsen, and A. Rip, eds., Techniek in Nederland in de twintigste eeuw, vol. 1 [Zutphen, 1998], 120.)

western Netherlands to regulate water distribution there. This complex of seventeen sea locks was also completed in 1970, making it possible to divert sufficient water to the Nieuwe Waterweg in Rotterdam even when river levels were low, and thus prevent the Nieuwe Waterweg from silting up. Because of the Haringvliet locks the western Netherlands possessed a large freshwater reservoir (created by the cut-off sea inlets), while the northern Netherlands benefited from this same supply due to the construction of what is known as the barrier dike (at the IJsselmeer). With fitting pride a 
prominent Rijkswaterstaat engineer of the day wrote: "[N] ever before had such a complicated river flow area been so completely subjected to human regulation." 30

The Rijkswaterstaat became the ruler of the delta. In the 1930s it even predicted the disastrous flood of 1953, which claimed eighteen hundred lives. Though the Rijkswaterstaat alerted the government to the danger, during the Second World War and the ensuing period of recovery the threat of the waterwolf had faded from people's minds. Furthermore, the majority of the country's seawalls were administered by the water boards and not by the Rijkswaterstaat. After the disaster the agency was able to fall back on existing plans and immediately begin work on the large-scale Delta Works project. $^{31}$ This project would bring the Rijkswaterstaat worldwide fame and give the Netherlands a permanent image as conqueror of the sea.

In the 1950s and 1960s the Rijkswaterstaat exerted thorough control over water management in the Netherlands. It built new hydraulic systems, new water bulwarks, and new infrastructure facilities according to its own plans and ideas. Many of the projects were not even legally approved, and often approval was granted only after the fact. But it would be going too far to claim that the Rijkswaterstaat had absolute power. The agency had to negotiate with numerous parties, and the water boards and provinces still had a part to play in the field of public works. Relations within the water polity (waterstaatsbestel) had altered thoroughly since the end of the nineteenth century. The Rijkswaterstaat had become the dominant player, building important works, controlling extensive money flows, and determining the conditions under which subsidies for water management projects were granted. The provinces confined themselves to the supervision of the water boards and their works. The number of water boards had increased substantially because of the exploitation of the sandy soils in the south and east of the Netherlands. Around 1940 there were 2,700 water boards in the Netherlands, though only the regional water boards played an important role in water management.

Many small water boards had such limited expertise and financial capacity that they constituted just minor opponents for an organization like the Rijkswaterstaat. Nevertheless, several small water boards administered important dikes, and the flood of 1953 demonstrated their shortcomings. As a result, the system of water boards was severely discredited and begin-

30. H. A. Ferguson, Benedenrivieren in de jaren zestig (The Hague, 1994), 34.

31. See E. de Boer, "Zestig jaar Deltawerken: Dordrecht als opening en sluitpost," in van Nispen, Lintsen, and Veenendaal, Nederlandse ingenieurs en hun kunstwerken, 197210; H. A. Ferguson, Delta-visie: Een terugblik op 40 jaar natte waterbouw in Zuidwest Nederland (The Hague, 1988) and Dialoog met de Noordzee: 2000 jaar Deltawerken (Hippolytushoef, 1991); I. Haagsma, De Deltawerken: Techniek, politiek, achtergronden (Delft, 1984); and S. Leydesdorff, Het water en de herinnering, de Zeeuwse watersnoodramp (Amsterdam, 1993). 
ning in the 1970s was transformed totally. The number of water boards was reduced (they presently number about sixty), and their responsibilities were extended; not only would the water boards be responsible for controlling water levels, they would also have a role in ensuring water purity, through wastewater treatment and the like. The water boards would carry out these tasks in conformity to directives formulated by ministers and provinces and

JULY

2002

VOL. 43 in dialog with social organizations in the areas of environmental research, nature and landscape, recreation, and national health. ${ }^{32}$

Quite unexpectedly around 1970 the tide also turned for the Rijkswaterstaat, catching the agency completely unawares. The heroes of the Delta Works were quickly demoted to the status of shortsighted engineers, authoritarian specialists, asphalt freaks, environmental polluters, and landscape destroyers. The reasons for this turn of events ran deep. The postwar rebuilding efforts of the Netherlands had succeeded; the country had become highly industrialized and prosperous. The 1970s saw explosive growth in the environmental movement. The belief in progress crumbled, and modern technology came under attack. The Rijkswaterstaat's credibility was undermined.

The protest mounted against river dike improvement perhaps best illustrates the situation. After the 1953 flood, safety norms for both the sea bulwark and the river network were tightened. That meant that the river dikes had to undergo major changes. The twisting dikes, still following the same patterns as they had in the Middle Ages, had to be straightened, given wider bases and gentler slopes, and made as free as possible of trees and undergrowth, a process that would transform the river landscape. It took some time before the project could be commenced, but by 1970 people were ready to begin. But they met immediate opposition from environmentalists, and activities had to be suspended. Eventually new design concepts were introduced to the project: rural beauty, biodiversity, and monumental structures, all of which conflicted sharply with safety, the pivotal consideration in the classical approach to river improvement. The protest was voiced by an intellectual elite-journalists, academics, writers, and artists. They were opposed by a powerful block of public works organizations (water boards, provincial works departments, and the Rijkswaterstaat), backed by the government and parliament. The debate reached a state of deadlock and dragged on for a further twenty years.

32. A large number of interested parties (homeowners, businesses, inhabitants, and others) are represented on the water boards, so that they are no longer organizations made up only of landowners with predominantly agricultural interests. Van de Ven, Man-Made Lowlands (n. 2 above), 174-78. 


\section{Integral and Interactive}

In the 1970s and 1980s the Rijkswaterstaat also had to contend with poor economic conditions. ${ }^{33}$ In the 1980s national government budgets decreased and funding for large public works projects dried up. The number of people employed by the Rijkswaterstaat fell from around fourteen thousand in 1982 to ninety-six hundred in 1994. The turning point came in the mid-1990s, when, for the first time in years, public works budgets started to increase and personnel numbers began to rise again. There were also signs of a cultural change. Beginning in the 1970s and 1980s, biologists, planners, behavioral experts, and administrators had streamed into the department, and even engineers who had been part of the protest movement had begun to join its ranks. They brought with them a new language and culture. The Rijkswaterstaat became less formal, and the environment and the landscape became key issues. Still, it would take some time before the "new" Rijkswaterstaat could take a leading role again on important public works questions.

The deadlock on river dikes was not resolved by the Rijkswaterstaat. It took two government commissions (one in 1975 and one in 1992) to give the required emphasis to new concepts in hydraulic engineering practice. Their analyses did indeed prove that the official plans would be detrimental to the landscape. It was suggested that much of that damage might be avoided, and they lobbied for greater creativity and more effort on the part of the designers of new dikes. In many cases special structures and construction methods, such as coffer dams, seepage barriers, and bascule dams, were more successful than traditional methods. A number of experiments aimed at restoring the natural Dutch river landscape were also central.

Even these developments were not enough to speed up the stagnated dike improvement plans. It was only when rivers rose to very high levels, as happened in 1993 and 1995, and panic broke out in river regions that something started to be done. Floods were prevented just in time. Afterward a new policy was quickly developed. Remarkably, preserving features of the landscape and encouraging natural development to continue was automatically integrated into the new plans.

The Rijkswaterstaat is now at the beginning of a new era. It has been predicted that infrastructure project investments will total around one hundred billion guilders in the years 2000 to 2010 and two hundred billion guilders from 2000 to 2020. A large portion of this work will be completed by the Rijkswaterstaat, but in a completely different way than in the 1950s and 1960s. If the "underground" tendencies of the 1970s and 1980s are pur-

33. See Bosch and Van der Ham, Twee eeuwen Rijkswaterstaat (n. 1 above), 285-304; van der Ham, Heersen en Beheersen (n. 1 above), 309-62; and Disco, "Waterstaat" (n. 27 above), 199-207. 
sued, then "interactive" and "integral" will be the key words for the Rijkswaterstaat in the next era. "Interactive" has to do with creating a foundation by closely involving social groups in the design, decision-making, and execution processes. "Integral" has to do with endeavoring to reconcile all the various interests and values, notably safety, economy, and ecology.

In the context of the long history of Dutch water management, the Rijkswaterstaat is a relatively young organization. It has had to win its place among institutions whose traditions go back centuries, the water boards and the provinces. Political circumstances have been of decisive importance in achieving this goal. The job ahead for the Rijkswaterstaat is a difficult one. Part of the country will have to be completely reorganized because of changes to agricultural practice. Urban developments are placing both the city and the country under pressure. International trade, freight transport, and increasing industry also require that adaptations be made in the physical infrastructure. Road traffic seems to be an almost unresolvable problem. Because of all these questions and the attendant administrative complexity, spatial planning finds itself at an impasse. Last but not least, there is the eternal battle against water. Sea levels will continue to rise, the Dutch landmass will continue to sink, and the rivers will continue to be unpredictable. 